\title{
Crosstalk between HIV and hepatitis C virus during co-infection
}

Paul J Rider ${ }^{1}$ and Fenyong Liu, ${ }^{1,2^{*}}$

\begin{abstract}
An estimated one-third of individuals positive for HIV are also infected with hepatitis C virus (HCV). Chronic infection with HCV can lead to serious liver disease including cirrhosis and hepatocellular carcinoma. Liver-related disease is among the leading causes of death in patients with HIV, and individuals with HIV and HCV co-infection are found to progress more rapidly to serious liver disease than mono-infected individuals. The mechanism by which HIV affects HCV infection in the absence of immunosuppression by HIV is currently unknown. In a recent article published in BMC Immunology, Qu et al. demonstrated that HIV tat is capable of inducing IP-10 expression. Further, they were able to show that HIV tat, when added to cells, was able to enhance the replication of HCV. Importantly, the increase in HCV replication by tat was found to be dependent on IP-10. This work has important implications for understanding the effect HIV has on the outcome of HCV infection in COinfected individuals. The findings of Qu et al. may inform the design of intervention and treatment strategies for co-infected individuals.

Please see related article: http://www.biomedcentral. com/1471-2172/13/15.
\end{abstract}

Keywords: Co-infection, HIV, HCV, IP-10

\section{Background}

A significant number of individuals with HIV are coinfected with serious human pathogens such as hepatitis $\mathrm{C}$ virus ( $\mathrm{HCV}$ ), which infects up to 170 million people globally [1]. Due to similar routes of infection for HIV and $\mathrm{HCV}$, it is estimated that up to a third of people with HIV are co-infected with HCV [1-3]. With an estimated 34 million cases of HIV infection worldwide [4],

\footnotetext{
*Correspondence: liu_fy@uclink4.berkeley.edu

${ }^{1}$ School of Public Health, University of California, Berkeley, CA 94720, USA

Full list of author information is available at the end of the article
}

this represents a disease burden for individuals with coinfection of HIV and HCV of greater than 10 million people. Prior to the era of effective anti-retroviral therapy, patients with HIV did not live long enough to suffer disease caused by chronic infection with $\mathrm{HCV}$. However, as a result of the effectiveness of current antiretroviral therapies, these individuals with HIV and $\mathrm{HCV}$ co-infection are now living long enough to be affected by disease caused by chronic HCV infection.

Liver-related disease is a leading cause of death in individuals infected with HIV, mostly due to co-infection with HCV $[1,5,6]$. There is an abundance of evidence that the normal progression of $\mathrm{HCV}$ pathogenesis is altered in the presence of HIV [7-10]. These studies have shown that individuals co-infected with HIV and HCV possess higher levels of HCV RNA, and progress more rapidly to serious liver disease, including cirrhosis and hepatocellular carcinoma [11]. Individuals with an HIV and HCV co-infection are also more resistant to standard HCV treatments than patients with an $\mathrm{HCV}$ mono-infection. For example, successful treatment with interferon/ribavirin in patients with an HCV genotype 1 mono-infection reaches $50 \%$ to $80 \%$ while in co-infected individuals effective treatment is reduced to $20 \%$ to $35 \%$ [1]. The mechanisms by which HIV affects HCV infection in individuals with a co-infection are currently unknown.

\section{IP-10 and HIV and HCV co-infection}

A number of research groups have sought to determine how HIV infection affects HCV in individuals that are co-infected. Multiple studies have identified elevated IP10 (CXCL10) levels as a negative prognostic indicator for both HCV infection and HIV and HCV co-infection [12-14]. Further, elevated IP-10 levels were associated with the poor response to interferon/ribavirin therapy noted above [15]. IP-10 is a CXC chemokine that binds to the CXCR3 immune system receptor present on a number of cells, including monocytes, natural killer cells and T-cells [16]. Binding of IP-10 to CXCR3 induces
C Biomed Central 
chemotaxis of stimulated cells to sites of infection or injury. It is thought that elevated IP-10 could recruit Tcells from the periphery and within the liver, mediating the damage seen in cirrhosis and hepatocellular carcinoma [17]. The mechanism by which elevated levels of IP-10 may affect HCV infection in individuals with HIV and $\mathrm{HCV}$ co-infection is not known.

Work by $\mathrm{Qu}$ et al., published in BMC Immunology, describes a potential molecular mechanism for the influence HIV has on HCV infection in individuals with HIV and HCV co-infection. Specifically, Qu et al. present findings describing a potential cause-and-effect relationship between HIV infection and increased HCV replication. HIV tat is shown to increase levels of IP-10 mRNA and protein and consequently enhance $\mathrm{HCV}$ replication. Importantly, IP-10 induction by tat is shown to be necessary and sufficient to increase $\mathrm{HCV}$ replication levels. Their data further demonstrate a synergism in the ability of HIV and HCV to induce IP-10: hepatocytes that were both infected with $\mathrm{HCV}$ and treated with HIV tat induced higher levels of IP-10 mRNA and protein than either $\mathrm{HCV}$ infection or treatment with HIV tat alone.

\section{Understanding co-infection}

It is challenging for many to imagine a situation in which both HIV and HCV would find themselves in the same cell and thus in a position to affect the replication of one another. However, specialized immune cells, called peripheral blood mononuclear cells and Kupffer cells, are sites of infection for both HIV and HCV and the possibility exists that both HIV and HCV could find themselves in the same cell in an individual with a coinfection [18]. Experiments should be carried out to determine if tat-induced IP-10 can affect HCV replication in Kupffer cells and peripheral blood mononuclear cells. However, an interesting implication of the work presented by $\mathrm{Qu}$ et al. is that HIV does not need to be present in the same cell to exert an effect on $\mathrm{HCV}$ infection. Both tat [19] and IP-10 can act on cells distant from the site of HIV infection.

The work by $\mathrm{Qu}$ et al. poses many intriguing and important questions. Certainly it is important to determine the mechanisms by which HIV upregulates IP-10 expression and, more importantly, how IP-10 enhances $\mathrm{HCV}$ replication. CXCR3 receptor expression is not known to be expressed on hepatocytes [16]; thus, in the experiments described by Qu et al., IP-10 may be acting through an as yet unknown mechanism. Additionally, it was recently shown that induced IP-10 in patients with $\mathrm{HCV}$ infection was expressed in a truncated, antagonist form [20]. Cellular proteinases responsible for the conversion of IP-10 to its antagonist form are presumably absent in the experiments performed by $\mathrm{Qu}$ et al. It will be interesting to determine which form is important in individuals who are co-infected and whether the antagonistic IP-10 has a similar influence on HCV replication as found in the paper.

There are reports of a genotype-specific response to HCV treatments [15] and it will be necessary to determine whether IP-10's effect on HCV is genotype specific. Similar experiments will need to be performed using multiple genotypes. Further, these findings will need to be addressed in an in vivo setting, such as a humanized mouse or primate model, to assess the relevance of these findings to the pathogenesis of HIV and HCV coinfection. IP-10 is the only chemokine examined by $\mathrm{Qu}$ et al.; however, multiple chemokines are found to be differentially regulated in individuals with HCV-associated liver disease [17]. It will be important to determine if other chemokines are able to enhance $\mathrm{HCV}$ replication as shown in the paper by $\mathrm{Qu}$ et al.

An important consideration for HIV co-infection studies is whether the effect measured is due to HIV or whether the effect can be attributed to the immunodeficiency that defines AIDS [1]. The relationship between $\mathrm{HIV}$ and pathogens such as HCV in individuals with a co-infection is not simply one of opportunism, whereby the immunodeficiency caused by HIV creates a situation in which normally non-pathogenic organisms can cause disease. Rather, the direct or indirect interplay between pathogens in individuals with co-infection is presumed to alter the normal progression of the disease seen in individuals with a mono-infection. In the study by $\mathrm{Qu}$ et $a l$., individuals who had progressed to AIDS (as determined by CD4 and CD8 counts) were included in the cohort to show a correlation between HIV, HCV and IP-10 levels. It will be important in future experiments to exclude individuals with an immunodeficiency as this confounds the interpretation of the effect of HIV infection on HCV viral load and IP-10 levels in those individuals. The low CD4 counts are likely responsible for some increase in HCV replication and, perhaps, the IP10 levels reported. Still, the finding that upregulation of IP-10 expression by HIV tat can enhance the replication of HCV illuminates IP-10 and HIV tat as targets for therapeutic intervention in individuals co-infected with $\mathrm{HIV}$ and $\mathrm{HCV}$.

\section{Conclusions}

The work presented by $\mathrm{Qu}$ et al. advances our understanding of the relationship between HIV and HCV in individuals with a co-infection, an area that is extremely important yet poorly understood. These findings have important implications for the rational design of therapeutic intervention to treat or prevent $\mathrm{HCV}$ liver disease in both individuals with $\mathrm{HIV}$ and $\mathrm{HCV}$ co-infection as well as those with an HCV mono-infection. 


\section{Acknowledgements}

The authors have been supported by grants from the National Institutes of Health (AI041927, DE014145, and DE014842).

\section{Author details}

${ }^{1}$ School of Public Health, University of California, Berkeley, CA 94720, USA. ${ }^{2}$ Program in Comparative Biochemistry, University of California, Berkeley, CA 94720, USA.

\section{Authors' contributions}

PJR and FL wrote, read and approved the final manuscript.

\section{Authors' information}

PJR and FL are currently affiliated with and conducting research at School of Public Health, University of California at Berkeley, USA.

\section{Competing interests}

The authors declare that they have no competing interests.

Received: 24 February 2012 Accepted: 3 April 2012

Published: 3 April 2012

\section{References}

1. Operskalski EA, Kovacs A: HIV/HCV co-infection: pathogenesis, clinical complications, treatment, and new therapeutic technologies. Curr HIV/ AIDS Rep 2011, 8(1):12-22

2. Alatrakchi N, Koziel MJ: A tale of two viruses: hepatitis $C$ in the age of HAART. Lancet 2003, 362:1687-1688.

3. Chen SL, Morgan TR: The natural history of hepatitis C virus (HCV) infection. Int J Med Sci 2006, 3:47-52.

4. Global Summary of the HIV/AIDS epidemic, December 2010. [http:// www.who.int/hiv/data/2011_epi_core_en.png].

5. Weber R, Sabin CA, Friis-Møller N, Reiss P, El-Sadr WM, Kirk O, Dabis F, Law MG, Pradier C, De Wit S, Akerlund B, Calvo G, Monforte A, Rickenbach M, Ledergerber B, Phillips AN, Lundgren JD: Liver-related deaths in persons infected with the human immunodeficiency virus: the D:A:D study. Arch Intern Med 2006, 166:1632-1641.

6. Graham CS, Baden LR, Yu E, Mrus JM, Carnie J, Heeren T, Koziel MJ: Influence of human immunodeficiency virus infection on the course of hepatitis C virus infection: a meta-analysis. Clin Infect Dis 2001, 33:562-569.

7. Parodi C, Belmonte L, Bare P, de Bracco MM, Ruibal-Ares B: Impact of human immune deficiency virus infection on hepatitis $C$ virus infection and replication. Curr HIV Res 2007, 5:55-67.

8. Seeff LB: Natural history of chronic hepatitis C. Hepatology 2002, 36 : S35-S46.

9. Qurishi N, Kreuzberg C, Lüchters G, Effenberger W, Kupfer B, Sauerbruch T, Rockstroh JK, Spengler U: Effect of antiretroviral therapy on liver-related mortality in patients with HIV and hepatitis C virus coinfection. Lancet 2003, 362(9397):1708-1713.

10. Antonucci G, Goletti D, Lanini S, Girardi E, Loiacono O: HIV/HCV coinfection: putting the pieces of the puzzle together. Cell Death Differ 2003, 10(Suppl 1):S25-S26.

11. Soto B, Sánchez-Quijano A, Rodrigo L, del Olmo JA, García-Bengoechea M, Hernández-Quero J, Rey C, Abad MA, Rodríguez M, Sales Gilabert M, González F, Mirón P, Caruz A, Relimpio F, Torronteras R, Leal M, Lissen E: Human immunodeficiency virus infection modifies the natural history of chronic parenterally-acquired hepatitis $C$ with an unusually rapid progression to cirrhosis. J Hepatol 1997, 26:1-5.

12. Roe B, Coughlan S, Hassan J, Grogan A, Farrell G, Norris S, Bergin C, Hall WW: Elevated serum levels of interferon-gamma-inducible protein10 in patients coinfected with hepatitis C virus and HIV. J Infect Dis 2007, 196:1053-1057.

13. Berenguer J, Fernandez-Rodríguez A, Jimenez-Sousa MA, Cosín J, Zarate P, Micheloud D, López JC, Miralles P, Catalán P, Resino S: High plasma CXCL10 levels are associated with HCV-genotype 1, and higher insulin resistance, fibrosis, and HIV viral load in HIV/HCV coinfected patients. Cytokine 2012, 57(1):25-29.

14. Larrubia JR, Benito-Martinez S, Calvino M, Sanz-de-Villalobos E, Parra-Cid T: Role of chemokines and their receptors in viral persistence and liver damage during chronic hepatitis C virus infection. World I Gastroenterol 2008, 14:7149-7159.

15. Butera D, Marukian S, Iwamaye AE, Hembrador E, Chambers TJ, Di Bisceglie AM, Charles ED, Talal AH, Jacobson IM, Rice CM, Dustin LB: Plasma chemokine levels correlate with the outcome of antiviral therapy in patients with hepatitis C. Blood 2005, 106:1175-1182.

16. García-López MA, Sánchez-Madrid F, Rodríguez-Frade JM, Mellado M, Acevedo A, García MI, Albar JP, Martínez C, Marazuela M: CXCR3 chemokine receptor distribution in normal and inflamed tissues: expression on activated lymphocytes, endothelial cells, and dendritic cells. Lab Invest 2001, 81(3):409-418.

17. Helbig K, Ruszkiewicz A, Lanford RE, Berzsenyi MD, Harley HA, McColl SR, Beard MR: Differential expression of the CXCR3 ligands in chronic hepatitis $\mathrm{C}$ virus $(\mathrm{HCV})$ infection and their modulation by $\mathrm{HCV}$ in vitro. J Virol 2009, 83:836-846.

18. Balagopal A, Ray SC, De Oca RM, Sutcliffe CG, Vivekanandan P, Higgins Y, Mehta SH, Moore RD, Sulkowski MS, Thomas DL, Torbenson MS: Kupffer cells are depleted with HIV immunodeficiency and partially recovered with antiretroviral immune reconstitution. Aids 2009, 23(18):2397-2404.

19. Frankel $A D$, Pabo CO: Cellular uptake of the tat protein from human immunodeficiency virus. Cell 1988, 55:1189-1193.

20. Casrouge A, Decalf J, Ahloulay M, Lababidi C, Mansour H, Vallet-Pichard A, Mallet V, Mottez E, Mapes J, Fontanet A, Pol S, Albert ML: Evidence for an antagonist form of the chemokine CXCL10 in patients chronically infected with HCV. J Clin Invest 2011, 121(1):308-317.

\section{Pre-publication history}

The pre-publication history for this paper can be accessed here: http://www.biomedcentral.com/1741-7015/10/32/prepub

doi:10.1186/1741-7015-10-32

Cite this article as: Rider and Liu: Crosstalk between HIV and hepatitis C virus during co-infection. BMC Medicine 2012 10:32.

\section{Submit your next manuscript to BioMed Central and take full advantage of:}

- Convenient online submission

- Thorough peer review

- No space constraints or color figure charges

- Immediate publication on acceptance

- Inclusion in PubMed, CAS, Scopus and Google Scholar

- Research which is freely available for redistribution
Ciomed Central 